\title{
ATTITUDES AND REPURCHASE INTENTION OF CONSUMERS TOWARDS FUNCTIONAL FOODS IN HO CHI MINH CITY, VIETNAM
}

\author{
NHU-TY NGUYEN1,2,* \\ ${ }^{1}$ School of Business, International University, Vietnam \\ ${ }^{2}$ Vietnam National University HCMC; Quarter 6, Linh Trung ward, Thu Duc district, HCMC, Vietnam \\ *Corresponding author: nhutynguyen@gmail.com; nhutynguyen@hcmiu.edu.vn
}

\begin{abstract}
Although the demand of functional foods is increasing rapidly, and Vietnam is considered as a much potential market for the development of functional food market. However, there are many unsolved problems remaining in functional foods market, and these problems have never ceased to draw public attention and provoke debates. Thus, the purpose of this research is to investigate the factors affecting to consumers' attitude and how consumers' attitude affecting to consumer's repurchase intention. The research will be conducted based on the questionnaires' results collect from people who have used functional foods in Ho Chi Minh City, Vietnam. Questionnaires will be spread to consumers by hands and online survey. There are 260 responses are valid. The results show that there are four factors that positively affect to consumers' attitude. These are (1) Consumers' knowledge, (2) Perceived role, (3) Trust, (4) Subjective norms. Moreover, the findings also show that when people have positive feelings about products, they will increase their intention to products. Research also finds that trust is a direct relationship with consumers' repurchases intention. From this conclusion, the study gives some recommendations to increase consumers' attitude towards functional foods as well as the repurchase intention.
\end{abstract}

Received 2019-12-30; accepted 2020-01-27; published 2020-03-02.

2010 Mathematics Subject Classification. 91B42.

Key words and phrases. consumers' attitude, repurchase intention, functional foods.

(C)2020 Authors retain the copyrights of their papers, and all open access articles are distributed under the terms of the Creative Commons Attribution License. 


\section{INTRODUCTION}

\section{Research problems}

Although the demand of functional foods is increasing rapidly and Vietnam is considered as a much potential market for the development of functional food market [1]. However, there are many unsolved problems remains in functional foods market and these problems have never ceased to draw public attention and provoke debates. The biggest problem for Vietnamese company is building trust in consumers toward functional foods (according to dantri website in 2017).

In 2000, the number of Vietnamese people using functional food is only about 500,000, and they mostly live in big cities such as Ho Chi Minh city and Ha Noi. However, in 2017, this number rapidly increased up to 20 million people (above $21 \%$ of population). In which, only $20 \%$ people use domestic functional food product and the rest use foreign made products from South Korea, US, Japan, etc. (according to Vnexpress in 2018). The domestic products are dominated by foreign products. The first reason for this situation is that consumers in developing countries like Vietnam are often in favor of foreign goods rather than domestic goods ([2]; [3]; [4];[5]). Another reason is that advertising of functional foods exaggerates than the benefits for health they really are, and it breaks the trust of Vietnamese customer when they don't receive the benefits as advertisements. Moreover, the reason also comes from the low level of knowledge and the unconsciousness about functional foods. This led to the serious outcomes such as Functional foods and dangers behind advertising, overusing functional food being in danger on recent newspapers (according to datviet in 2018). Besides, Vietnamese are often affected by advice from people around them such as their relatives or their friends and make decisions.Secondly, With the rapidly increasing of functional food demand, although Vietnamese authorities have formulated policies for developing domestic products and tightly controlling the quality of functional food in Vietnam, there exists the large quantity of fake and poor good quality products based on the incoherence of legal systems and policies. As a result, functional foods market lose consumers' trust towards products ([6]; [7])

Therefore, understanding these problems,this research is carried out with the purpose of understanding profoundly into consumers' behavior by examining the influence of perception factors to consumers' attitude and how consumers' attitude affecting to their repurchase intention as well as investigatingthe incentives behind their repurchase intention. Moreover, this research also recommends some solutions based on the results of research. It can 
be practical for Vietnamese enterprises and authorities to develop functional food market and attract customers. The research will be conducted in Ho Chi Minh City market and general functional foods.

\section{Research objectives}

The purposes of this study are proposed as follow:

$\checkmark$ Examine the influential factors on consumer attitude towards functional food in a rapid growing market

$\checkmark$ Explore the impact of attitude on repurchase intention

$\checkmark$ To understand the problems and challenges, propose solutions for improving consumers' attitude and repurchase intention, increasing competitiveness of Vietnamese functional food products and supporting Vietnamese authorities in developing and managing the market

\section{Research Questions}

With these purposes, the research are raised to achieve the research purposes

$\checkmark$ What kind of factors influence consumers' attitude toward functional foods?

$\checkmark$ How does consumers' attitude impact on consumers' repurchase intention toward functional foods product?

$\checkmark$ What are the recommendations to enhance the consumers' attitude and repurchase intention toward the products?

\section{LITERATURE REVIEW}

\section{Conceptual model review}

This study is carried out to understand about consumers' behaviors and how consumers attitude affecting to consumers' repurchase intentionby adapting a model form the research" Consumer attitude and purchase intention towards organic food - A case study in China" conducted by Mingyan Yang, Sarah Al-Shaaban and Tram B. Nguyen. The research was undertaken in 2014 [8] in order to explore the factors affecting consumers' attitude and the impact of consumers' attitude on consumer's purchase intention towards organic food. 


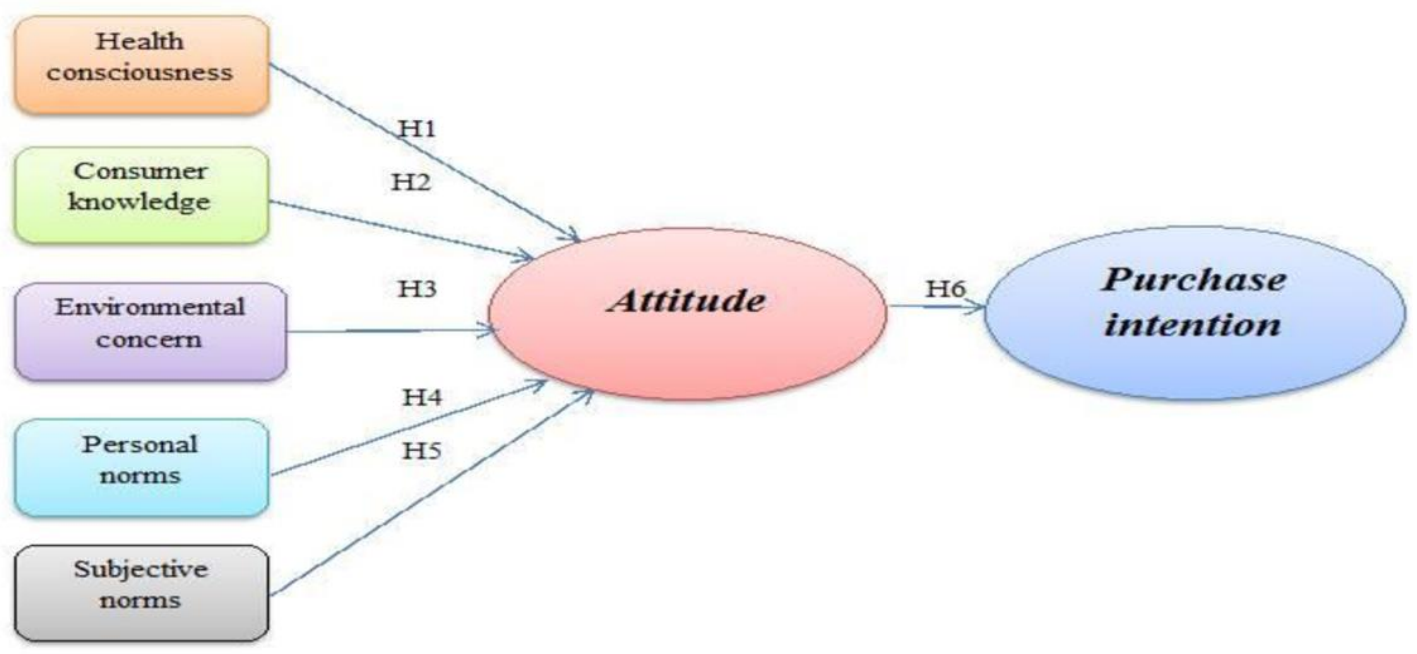

Figure 2.1 Research model ofMingyan Yang, Sarah Al-Shaaban and Tram B. Nguyen

By adapting the Theory of Planned Behavior [9] which illustrated that "behavioral intention refers to an individual's subjective likelihood of performing a certain behavior" and "intention can be related to attitude in some extent", the model they studied including five factors "Health consciousness", “Consumer Knowledge", "Environmental Concern", "Personal Norms" and Subjective Norms", the mediating factor "Attitude" and the dependent variable "Purchase Intention". The research examined that consumer knowledge; personal norms and health consciousness are the key important factors that influence to consumer's attitude and purchase intention. Moreover, the findings also found that consumers have positive attitude towards functional foods will be more likely to purchase them ([2]; [10]; [1]).

There are many researchers in Vietnam have conducted study to consumer's acceptance and consumers' purchase intention; however; there has not been any study about consumers' repurchase intention and their attitude toward functional food, especially in Ho Chi Minh city ([11]; [12]; [13]; [14]). Besides, consumers' attitude can be significantly different from countries to countries. Therefore, the study will based on this model and adjust to make it applicable in Vietnam market.

\section{Research concepts}

\subsection{Consumers' repurchase intention}

The concept of repurchase intention means the future intention to use good or service ([15]). According to Jackson's points of view ([16]), "repurchase intention" like "consumer behavioral intention" that measure the tendency towards using rate of customers about such as continuing, 
increasing or decreasing the amount of good or services. The decision of reselecting the same goods and services are explained by the good experiences about products such as perceived product quality, price or trust they have been through. From consumer perspective, consumer attitude and commitment to purchase a certain product is the consequence of repurchase intention ([1]).

In this research, repurchase intention towards functional foods is the likelihood that consumers will continue to buy functional foods in Ho Chi Minh city.

\subsection{Consumers' attitude}

Consumers' attitude describes the consumers' feeling which is negative or positive towards an object and activities ([17]). According to ([18]), attitude is defined as the emotion of people in evaluating an object or activities. According to ([19]), consumers' attitude can make consumption behavior happen such as how frequently people go shop food. People who have more positive attitude have a tendency to buy more products ([20]). Besides basing on experiences, consumers' attitude also comes from the expectations and beliefs about products ([9]; [20]; [21]).

In the previous researches, theory of planned behavior (TPB) is often applied to examine the consumers' attitude ([21]; [20]).

\section{H6: Consumers' attitude has positive relationship to consumers' repurchase intention}

\subsection{Consumer knowledge}

The biggest difference between developing functional foods and normal foods is the requirement of scientific evidences; therefore, the research process needs experts from many fields in order to have these evidences ([22]). In a quality research 1999, IFCF pointed out that knowledge and trust are the key motivation for buying and using or not using functional foods in diet. The higher levels of knowledge consumers have towards functional foods, the higher cognitive capacity and exact performance they have ([23]). Consumers can gain knowledge from various channels such as social media, social networks, health experts and advertisements. When they have high knowledge about functional foods, they can easily make right decisions to choose or refuse product.

\section{H1: There is a positive relationship between consumer knowledge and consumers' attitude}




\subsection{Price}

Ares et al. (2010) [24] conclude that high prices may affect consumers' intention to buy in two ways: reducing the intention to buy due to spending too much on the product, or positively affect purchasing intention because it creates better perception about product quality. The research of Annunziata and Vecchio (2012) [25] demonstrates that different groups of customers have different ways of evaluate the importance of prices. There are many people think that functional foods with higher price must go with higher quality. With these consumers, they have high income and are willing to pay for healthier alternatives regardless of price. On the other hands, Verbeke (2005) [20] also indicates that one of the main barriers for consumers' attitude and intention relates to very high price. Several consumers prefer good quality functional foods with affordable price. They will consider wasting or saving before buying functional foods. Childs (1997) [26] concludes that price and perceived price are better predicted factors (compared to trust) for the purchase habit of functional foods in the future. This leads the suggestion for this study to focus on perceived price as a determinant of acceptance and purchase.

\section{H2: There is a positive relationship between Price and Consumers' attitude}

\subsection{Subjective norms}

Subjective norms are defined as the perceived social pressure on to perform or not perform actions ([9]).

Subjective norms are decisively factor that is widely applied to understand about human behavior ([27]). It has been said that "although many people think of themselves as individuals, people, most of the time, look to others for guidance in how to behave" and they may feel "unwanted emotions" when not act like others ([27]). In marketing sector, many researchers claim that Subjective norms are the key factor determine consumers' purchasing intention and ([28], [29]). According to Shepherd, (1999) [30], choosing foods is influenced by many factors including subjective norms factors.

The previous researches proved the relationship between subjective norms (foods other people claim that I should eat) and the amount of food using ([31]). According to Aarts and Dijksterhuis, (2003) [21], a special feature of these standard influences is that its impact seems unconscious, and people often deny that they are influenced by others.

H3: There is a positive relationship between Subjective norms and Consumers' attitude 


\subsection{Trust}

As cited in Carmina and Carlos (2011, p.283), Moorman et al. (1993) [32] defined: "Trust as a willingness to rely on an exchange partner in whom one has confidence."

Because of the awareness of the roles of foods for health, consumers believe functional foods play an important role for protecting and improving people's health ([28]). Citizens in developed countries increasingly have more responsibility for their health and they claim that food and diet have relationship with people's health ([33]). According to the research of Niva (2007) [34], consumers are more health conscious, and they are willing to change their eating habits to have a better health.

If the perceived role of functional foods for health mainly includes general aspects about recognizing about the important of health, controlling and orientation behaviors, trust in the context of functional foods definitely relates to perceived benefits of functional foods for health ([20]). Therefore, the hypothesis is proposed as follow:

\section{H4: There is a positive relationship between Trust and Consumers' attitude}

\subsection{Perceived role}

Perceiving roles of functional foods for health plays an important part in affecting functional foods acceptance. In the previous research, there are various concepts about trust and roles of

functional foods and these concepts come from the effect of themselves on health ([35]), have consciousness about health requirements ([36]). In the research "Functional Food Choices: Impacts of Trust and Health Beliefs" ([31]). The author states that both trust and health perceived are the key factors affecting to consumer' attitude.

H5: There is a positive relationship between Perceived role and Consumers' attitude 


\section{Proposed research model}

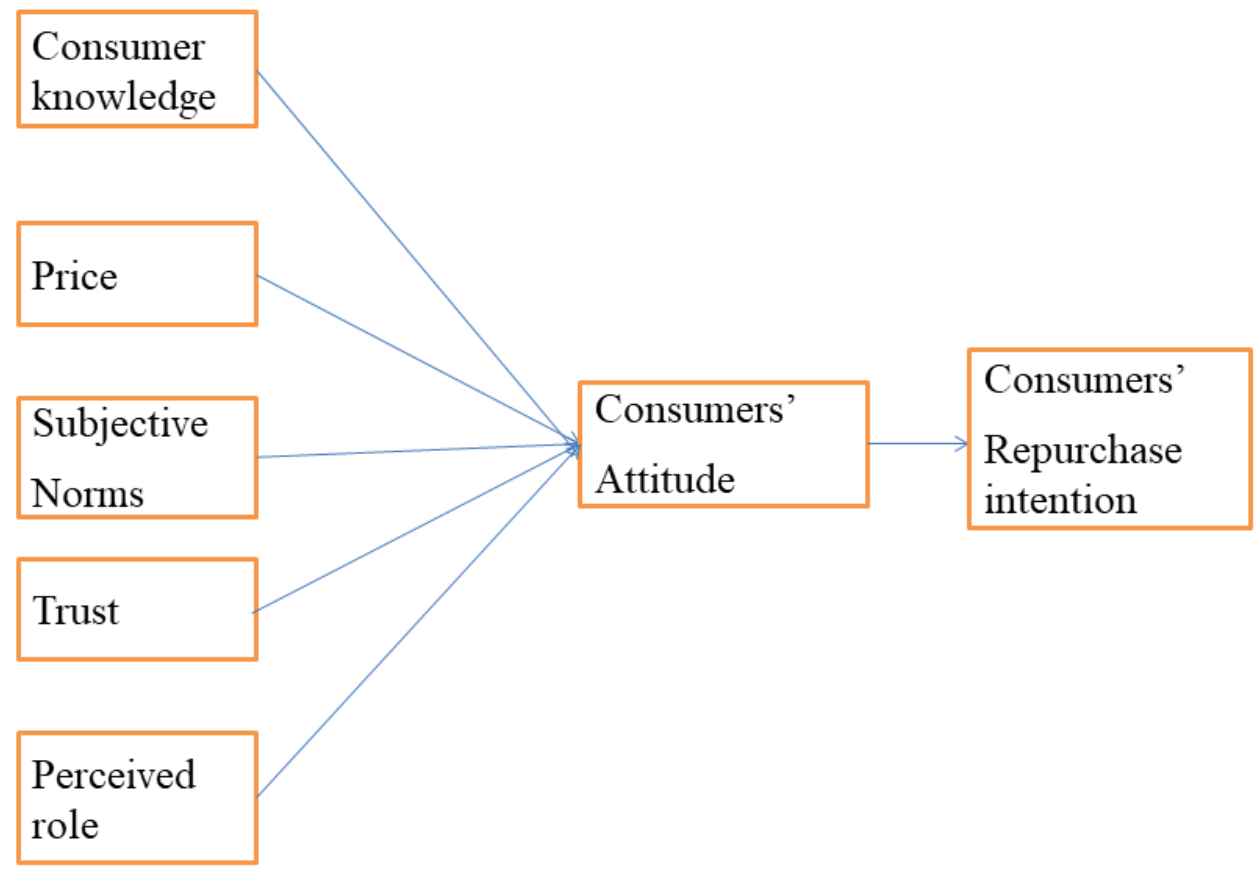

RESEARCH METHODOLOGY

\section{Research design}

This research is conducted to test the feasible factors affecting to consumers' attitude towards functional foods and the relationship between attitude and repurchase intention. It will be based on the previous researches and theoretical frameworks in order to develop six hypotheses. This is the reason why deductive research method will be appropriate to be implemented in this case. Moreover, empirical data is collected by using survey questionnaire with the purpose of testing the existing theories and modifying mode. From this point of view, deductive approach completely satisfies this requirement.

With the purpose of collecting, analyzing and generalizing data, quantitative research will be implemented along with deductive research. Specifically, the quantitative approach is appropriate in this circumstance because the research intends to reach a large number of consumers in Ho Chi Minh City by survey questionnaires. Furthermore, the main objective of 
this research is to test the hypothesis and theoretical model based on the previous study. Therefore, quantitative method is fulfilled the requirements.

\section{Sample of research}

The conceptual model has 7 variables, in which 5 variables are independent and 2 variables are dependent. According to ([37]), the applicable sample size should be at least 150 and 200. With the limited financial ability and time period, the research will carry out 260 surveys

\section{Data collection method}

In this research, Primary data will be collected by giving online and offline survey to consumers from 10th April 2019 to $24^{\text {th }}$ April 2019. With this method, it is the best way to reach a large amount of consumers using functional foods. In specified, questionnaires will be directly delivered to each consumer by hands at public place or by social media channel such as Facebook, Zalo and so on.

\section{Questionnaire design}

The surveys are spread out among consumers in Ho Chi Minh city by hands or by social media channel such as Facebook, Zalo and so on. There are two parts in the questionnaire; the first is designed to collect demographic information including job, age, gender, income. It will help researcher understand about the target object. The left part is created based on the factors affecting to consumers' attitude, consumer's attitude and repurchase intention. The questionnaires have 26 question designed from the theoretical concepts.

The demographic part of questionnaires is designed in ordinal, nominal scale. The second part which is designed in order to measure the theoretical concept based on Likert measurement scale where 1 represents for totally disagree and 5 stands for totally agree. All questions are closed question, easy to understand and designed in Vietnamese language. Respondents chose one of the existing alternatives without expressing new opinion. With this method, it will ensure the related between data and conceptual model

\section{Data analysis method}

Data will be analyzed by using SPSS and AMOS software. Analysis method is chosen according to study objectives; therefore, this research will conduct the following analysis

○ Descriptive statistics

○ Reliability test

- Exploratory Factor Analysis (EFA)

- Confirmatory Factor Analysis (CFA)

- Structural Equation Modeling (SEM) 


\section{RESEARCH RESUlTS AND FINDING DISCUSSION}

\section{Demographic Analysis}

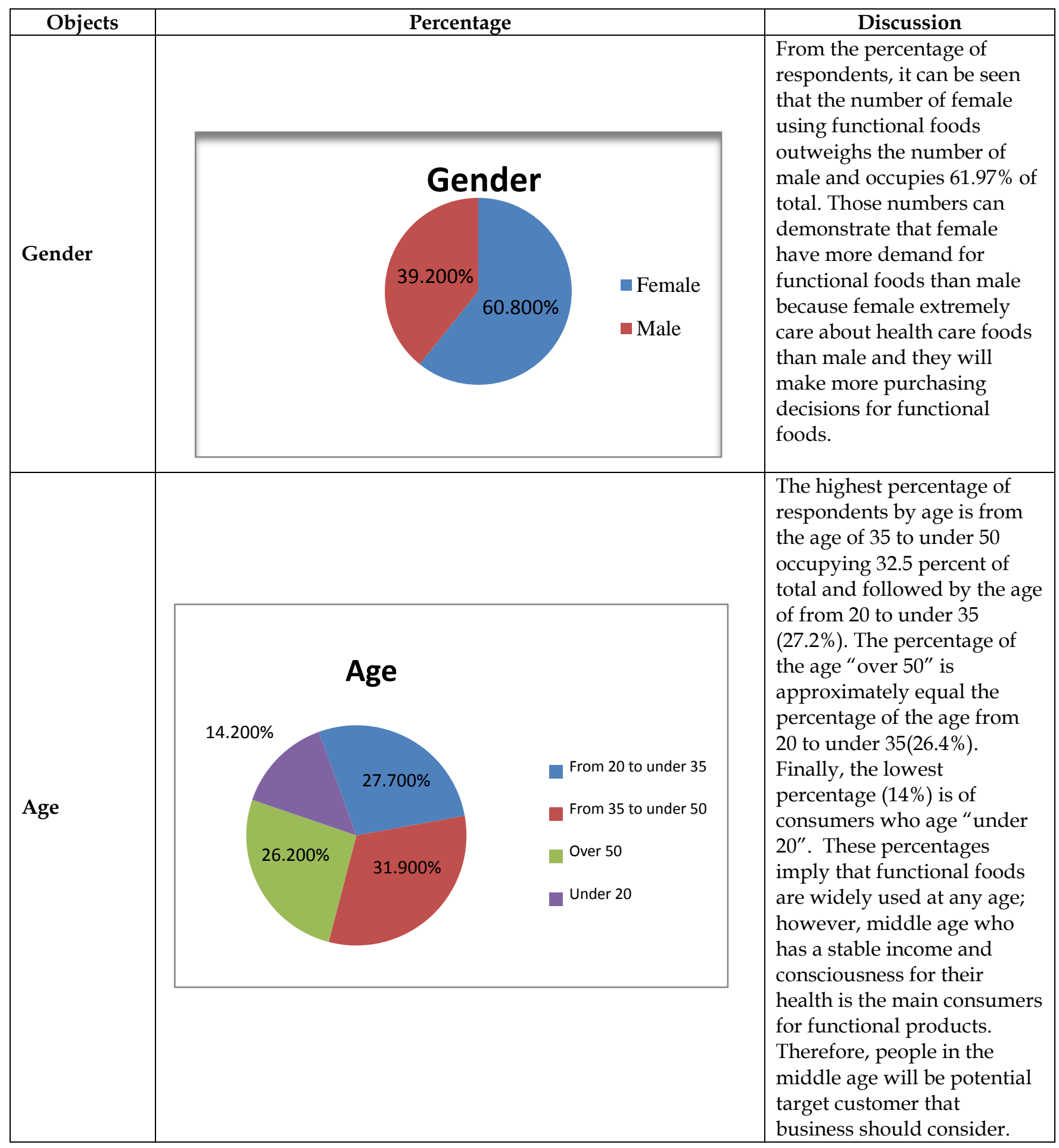




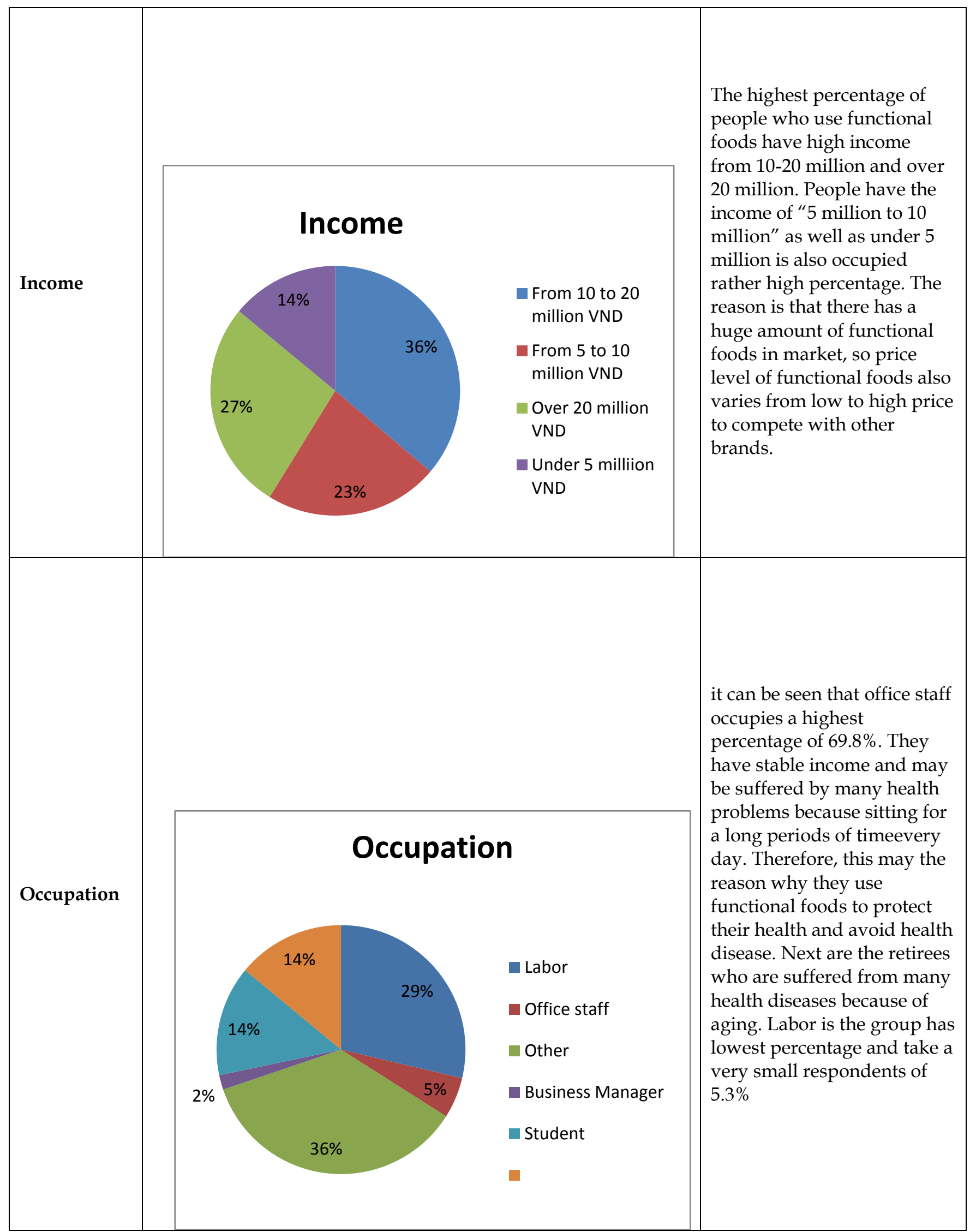




\section{Reliability test - Cronbach's alpha and Exploratory Factor Analysis (EFA)}

\begin{tabular}{|c|c|c|c|c|c|}
\hline & & \begin{tabular}{|r|} 
Scale Mean \\
if Item \\
Deleted \\
\end{tabular} & $\begin{array}{r}\text { Scale } \\
\text { Variance if } \\
\text { Item Deleted }\end{array}$ & $\begin{array}{r}\text { Corrected Item- } \\
\text { Total } \\
\text { Correlation } \\
\end{array}$ & $\begin{array}{r}\text { Cronbach's } \\
\text { Alpha if Item } \\
\text { Deleted }\end{array}$ \\
\hline \multicolumn{2}{|c|}{ Cronbach's Alpha } & & & & 0.859 \\
\hline SUN1 & $\begin{array}{l}\text { My relatives often use functional } \\
\text { foods in their diet }\end{array}$ & 10.29 & 5.930 & .771 & .793 \\
\hline SUN2 & $\begin{array}{l}\text { My relatives claim that using } \\
\text { functional foods brings benefits } \\
\text { for health }\end{array}$ & 10.21 & 6.654 & .636 & .853 \\
\hline SUN3 & $\begin{array}{l}\text { My friends often use functional } \\
\text { foods in their diet }\end{array}$ & 10.53 & 6.806 & .698 & .823 \\
\hline SUN4 & $\begin{array}{l}\text { My relatives often use functional } \\
\text { foods }\end{array}$ & 10.61 & 7.543 & .767 & .812 \\
\hline \multicolumn{2}{|c|}{ Cronbach's Alpha } & & & & .782 \\
\hline ROP1 & $\begin{array}{l}\text { Functional foods play an } \\
\text { important role for my health }\end{array}$ & 11.18 & 6.553 & .606 & .729 \\
\hline ROP2 & $\begin{array}{l}\text { I feel to have control over for my } \\
\text { health }\end{array}$ & 11.17 & 6.046 & .507 & .772 \\
\hline ROP3 & $\begin{array}{l}\text { I feel to use more functional foods } \\
\text { which bring more benefits for my } \\
\text { health as compared to } 5 \text { years ago }\end{array}$ & 11.10 & 5.449 & .627 & .708 \\
\hline ROP4 & $\begin{array}{l}\text { Functional foods can help me } \\
\text { improve my emotion }\end{array}$ & 11.24 & 5.510 & .637 & .703 \\
\hline \multicolumn{2}{|r|}{ Cronbach's Alpha } & \multicolumn{4}{|r|}{.827} \\
\hline PRK1 & $\begin{array}{l}\text { I clearly understand about } \\
\text { positive effects of functional foods } \\
\text { on my health }\end{array}$ & 10.12 & 7.685 & .733 & .746 \\
\hline PRK2 & $\begin{array}{l}\text { I highly appreciate my knowledge } \\
\text { about functional foods }\end{array}$ & 10.22 & 8.844 & .582 & .812 \\
\hline PRK3 & $\begin{array}{l}\text { I know using functional foods can } \\
\text { be likely help me improve my } \\
\text { health }\end{array}$ & 10.15 & 7.526 & .678 & .770 \\
\hline PRK4 & $\begin{array}{l}\text { I know using functional foods can } \\
\text { have side - effects }\end{array}$ & 10.12 & 7.542 & .631 & .794 \\
\hline \multicolumn{2}{|c|}{ Cronbach's Alpha } & & & & .835 \\
\hline PRI1 & $\begin{array}{l}\text { Functional foods are not so } \\
\text { expensive compared to the } \\
\text { enormous benefits they brings for } \\
\text { my health }\end{array}$ & 10.40 & 9.570 & .674 & .788 \\
\hline
\end{tabular}




\begin{tabular}{|c|c|c|c|c|c|}
\hline PRI2 & $\begin{array}{l}\text { I think that functional foods' price } \\
\text { which is higher than normal foods } \\
\text { is appropriate with their benefits }\end{array}$ & 10.24 & 8.763 & .641 & .810 \\
\hline PRI3 & $\begin{array}{l}\text { I always compare the price of } \\
\text { functional foods in different stores } \\
\text { before I buy them }\end{array}$ & 10.35 & 8.992 & .814 & .727 \\
\hline PRI4 & $\begin{array}{l}\text { The high price of function foods is } \\
\text { not the main reason for me to not } \\
\text { buy it }\end{array}$ & 10.23 & 10.813 & .563 & .834 \\
\hline & Cronbach's Alpha & & & & .841 \\
\hline ATI1 & $\begin{array}{l}\text { I like using functional foods in my } \\
\text { diet }\end{array}$ & 7.40 & 3.623 & .781 & .714 \\
\hline ATI2 & $\begin{array}{l}\text { Functional foods are suitable with } \\
\text { my health protection demand }\end{array}$ & 7.37 & 3.424 & .677 & .812 \\
\hline ATI3 & $\begin{array}{l}\text { I will be glad to suggest other } \\
\text { people using functional foods }\end{array}$ & 7.49 & 3.664 & .670 & .814 \\
\hline & Cronbach's Alpha & & & & .784 \\
\hline REI1 & $\begin{array}{l}\text { I experienced functional foods, } \\
\text { and I intend to continue to use it }\end{array}$ & 10.92 & 5.962 & .566 & .744 \\
\hline REI2 & $\begin{array}{l}\text { I intend to use more functional } \\
\text { foods in the future }\end{array}$ & 11.09 & 5.567 & .603 & .725 \\
\hline REI3 & $\begin{array}{l}\text { I plan to buy more types of } \\
\text { functional foods }\end{array}$ & 11.08 & 5.580 & .618 & .718 \\
\hline REI4 & $\begin{array}{l}\text { I will buy functional foods } \\
\text { regularly }\end{array}$ & 11.05 & 5.326 & .582 & .739 \\
\hline & Cronbach's Alpha & & & & .846 \\
\hline TRU1 & $\begin{array}{l}\text { Functional foods are likely to have } \\
\text { positive impacts on my health }\end{array}$ & 14.37 & 9.933 & .728 & .798 \\
\hline TRU2 & $\begin{array}{l}\text { Functional foods help me take my } \\
\text { personal health on my hands }\end{array}$ & 14.59 & 9.717 & .719 & .798 \\
\hline TRU3 & $\begin{array}{l}\text { Functional foods are a convenient } \\
\text { way of meeting daily nutrient } \\
\text { requirements that I never meet } \\
\text { with conventional diet }\end{array}$ & 14.48 & 9.077 & .667 & .813 \\
\hline TRU4 & $\begin{array}{l}\text { I can improve my personal health } \\
\text { by using functional foods }\end{array}$ & 14.37 & 9.693 & .632 & .821 \\
\hline TRU6 & $\begin{array}{r}\text { Safety levels of functional foods } \\
\text { are tested carefully }\end{array}$ & 14.56 & 10.463 & .546 & .842 \\
\hline
\end{tabular}

After conducting Reliability test, all independent variables meet the standard requirements of reliability will be retested by EFA to test the correlation andamong factors. From the results of table below, it can be seen that the value of $\mathrm{KMO}$ is $0.824(\geq 0.05)$ and the significance of Bartlett's test is $0.000(<0.05)$ demonstrates that extracting variables is acceptable andthere correlationbetween observed variables 
Table 4.20 KMO and Bartlett's Test

Kaiser-Meyer-Olkin Measure of Sampling Adequacy.

Bartlett's Test of Sphericity Approx. Chi-Square

df

Sig.

Total Variance Explained

\begin{tabular}{|c|c|c|c|c|c|c|c|}
\hline \multirow[b]{2}{*}{ Factor } & \multicolumn{3}{|c|}{ Initial Eigenvalues } & \multicolumn{3}{|c|}{$\begin{array}{l}\text { Extraction Sums of Squared } \\
\text { Loadings }\end{array}$} & $\begin{array}{l}\text { Rotation Sums of } \\
\text { Squared Loadings }\end{array}$ \\
\hline & Total & $\begin{array}{c}\% \text { of } \\
\text { Variance }\end{array}$ & $\begin{array}{c}\text { Cumulative } \\
\%\end{array}$ & Total & $\begin{array}{c}\% \text { of } \\
\text { Variance }\end{array}$ & $\begin{array}{c}\text { Cumulative } \\
\%\end{array}$ & Total \\
\hline 1 & 7.308 & 26.099 & 26.099 & 6.899 & 24.639 & 24.639 & 4.417 \\
\hline 2 & 2.687 & 9.596 & 35.695 & 2.316 & 8.273 & 32.911 & 4.023 \\
\hline 3 & 2.431 & 8.682 & 44.377 & 2.043 & 7.296 & 40.207 & 2.601 \\
\hline 4 & 2.111 & 7.540 & 51.917 & 1.675 & 5.983 & 46.190 & 4.176 \\
\hline 5 & 1.691 & 6.039 & 57.956 & 1.276 & 4.556 & 50.747 & 4.199 \\
\hline 6 & 1.537 & 5.488 & 63.444 & 1.106 & 3.952 & 54.698 & 3.181 \\
\hline 7 & 1.049 & 3.745 & 67.190 & .729 & 2.603 & 57.302 & 4.716 \\
\hline 8 & .883 & 3.152 & 70.342 & & & & \\
\hline 9 & .778 & 2.780 & 73.122 & & & & \\
\hline 10 & .694 & 2.480 & 75.602 & & & & \\
\hline 11 & .671 & 2.396 & 77.998 & & & & \\
\hline 12 & .628 & 2.244 & 80.242 & & & & \\
\hline 13 & .580 & 2.070 & 82.311 & & & & \\
\hline 14 & .520 & 1.859 & 84.170 & & & & \\
\hline 15 & .471 & 1.681 & 85.851 & & & & \\
\hline 16 & .463 & 1.655 & 87.507 & & & & \\
\hline 17 & .426 & 1.522 & 89.028 & & & & \\
\hline 18 & .411 & 1.467 & 90.495 & & & & \\
\hline 19 & .381 & 1.361 & 91.856 & & & & \\
\hline 20 & .361 & 1.290 & 93.146 & & & & \\
\hline 21 & .330 & 1.177 & 94.323 & & & & \\
\hline 22 & .299 & 1.067 & 95.390 & & & & \\
\hline 23 & .289 & 1.034 & 96.423 & & & & \\
\hline 24 & .243 & .869 & 97.292 & & & & \\
\hline 25 & .225 & .804 & 98.096 & & & & \\
\hline 26 & .211 & .755 & 98.850 & & & & \\
\hline 27 & .174 & .621 & 99.471 & & & & \\
\hline 28 & .148 & .529 & 100.000 & & & & \\
\hline
\end{tabular}

Extraction Method: Principal Axis Factoring.

a. When factors are correlated, sums of squared loadings cannot be added to obtain a total variance. 
Table 4.21 Pattern Matrix ${ }^{a}$

\begin{tabular}{|c|c|c|c|c|c|c|c|}
\hline & \multicolumn{7}{|c|}{ Factor } \\
\hline & 1 & 2 & 3 & 4 & 5 & 6 & 7 \\
\hline TRU1 & .896 & & & & & & \\
\hline TRU2 & .866 & & & & & & \\
\hline TRU4 & .643 & & & & & & \\
\hline TRU3 & .624 & & & & & & \\
\hline TRU6 & .552 & & & & & & \\
\hline SUN4 & & .897 & & & & & \\
\hline SUN3 & & .839 & & & & & \\
\hline SUN1 & & .773 & & & & & \\
\hline SUN2 & & .642 & & & & & \\
\hline PRI3 & & & .957 & & & & \\
\hline PRI1 & & & .723 & & & & \\
\hline PRI2 & & & .702 & & & & \\
\hline PRI4 & & & .644 & & & & \\
\hline PRK1 & & & & .896 & & & \\
\hline PRK3 & & & & .756 & & & \\
\hline PRK4 & & & & .704 & & & \\
\hline PRK2 & & & & .606 & & & \\
\hline REI2 & & & & & .804 & & \\
\hline REI3 & & & & & .761 & & \\
\hline REI4 & & & & & .601 & & \\
\hline REI1 & & & & & .522 & & \\
\hline ROP3 & & & & & & .765 & \\
\hline ROP1 & & & & & & .753 & \\
\hline ROP4 & & & & & & .737 & \\
\hline ROP2 & & & & & & .509 & \\
\hline ATI1 & & & & & & & .988 \\
\hline ATI3 & & & & & & & .627 \\
\hline ATI2 & & & & & & & .600 \\
\hline
\end{tabular}

Extraction Method: Principal Axis Factoring.

Rotation Method: Promax with Kaiser Normalization.

a. Rotation converged in 6 iterations.

From the Total Variance Explained table above, 6 factors are extracted with the cumulative (\%) of 57.302 percent. This illustrates that they can explicate around 57 percent of data variability. These observed variables have loading factors are greater than 0.5 which fulfill the conditions of convergent and discriminated validity.

\section{CFA test}

After conducting EFA, CFA is the next step which is employed to examine the measurement model before testing the relationship between factors by using the simultaneous equation model. 
In specific, CFA is aimed to test the consistence degree of constructional measures and the researchers' understanding of that construct.

In CFA test, p-value, convergent validity, discriminant validity and reliability should be taken into account to verify the conformity of model

\section{Figure 4.21 CFA test}

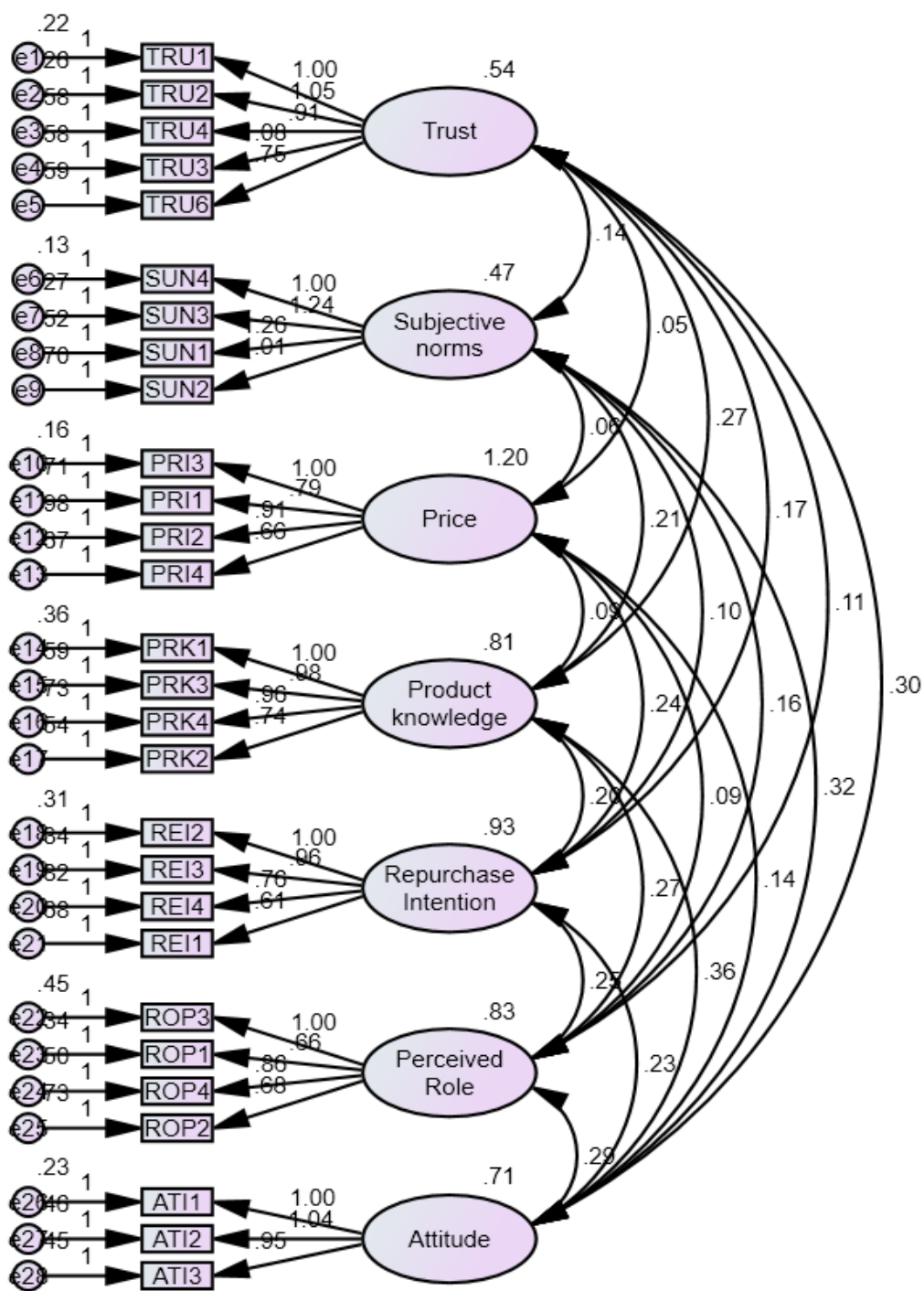

$$
\begin{array}{r}
\text { Chi-square=549.436; } \mathrm{df}=329 ; \mathrm{P}=.000 ; \\
\text { Chi-square } / \mathrm{df}=1.670 ; \\
\mathrm{GFI}=.874 ; \mathrm{TLI}=.925 ; \mathrm{CFI}=.934 ; \\
\mathrm{RMSEA}=.051
\end{array}
$$




\section{Testing the convergence and the reliability}

\begin{tabular}{|c|c|c|c|c|c|}
\hline & & & Estimate & AVE & CR \\
\hline TRU1 & $<<--$ & Trust & .841 & \multirow{5}{*}{0.539} & \multirow{5}{*}{0.851} \\
\hline \begin{tabular}{|l|} 
TRU2 \\
\end{tabular} & $<--$ & Trust & .836 & & \\
\hline TRU4 & $<--$ & Trust & .656 & & \\
\hline TRU3 & $<--$ & Trust & .720 & & \\
\hline TRU6 & $<<-$ & Trust & .582 & & \\
\hline SUN4 & $<--$ & Subjective_norms & .885 & \multirow{4}{*}{0.628} & \multirow{4}{*}{0.869} \\
\hline SUN3 & $<--$ & Subjective_norms & .855 & & \\
\hline SUN1 & $<<--$ & Subjective_norms & .768 & & \\
\hline SUN2 & $<--$ & Subjective_norms & .639 & & \\
\hline PRI3 & $<--$ & Price & .940 & \multirow{4}{*}{0.586} & \multirow{4}{*}{0.847} \\
\hline PRI1 & $\leftarrow$ & Price & .717 & & \\
\hline \begin{tabular}{|l|} 
PRI2 \\
\end{tabular} & $\leftarrow-$ & Price & .710 & & \\
\hline PRI4 & $\leftarrow$ & Price & .665 & & \\
\hline PRK1 & $\leftarrow$ & Product_knowledge & .832 & \multirow{4}{*}{0.555} & \multirow{4}{*}{0.832} \\
\hline PRK3 & $\leftarrow-$ & Product_knowledge & .754 & & \\
\hline PRK4 & $\leftarrow-$ & Product_knowledge & .712 & & \\
\hline PRK2 & $\leftarrow$ & Product_knowledge & .672 & & \\
\hline REI2 & $\leftarrow-$ & Repurchase_Intention & .867 & \multirow{4}{*}{0.551} & \multirow{4}{*}{0.827} \\
\hline REI3 & $<--$ & Repurchase_Intention & .848 & & \\
\hline REI4 & $<<-$ & Repurchase_Intention & .627 & & \\
\hline REI1 & $<--$ & Repurchase_Intention & .584 & & \\
\hline ROP3 & $<--$ & Perceived_Role & .806 & \multirow{4}{*}{0.514} & \multirow{4}{*}{0.807} \\
\hline ROP1 & $<<-$ & Perceived_Role & .717 & & \\
\hline ROP4 & $<--$ & Perceived_Role & .739 & & \\
\hline ROP2 & $<--$ & Perceived_Role & .588 & & \\
\hline ATI1 & $<<-$ & Attitude & .868 & \multirow{3}{*}{0.654} & \multirow{3}{*}{0.850} \\
\hline ATI2 & $<--$ & Attitude & .790 & & \\
\hline ATI3 & $<--$ & Attitude & .765 & & \\
\hline
\end{tabular}




\begin{tabular}{|l|l|l|}
\hline \multicolumn{1}{|c|}{ Measure } & \multicolumn{1}{c|}{ Results } & Gvaluation \\
\hline Chi - square/df (cmin/df) & 1.670 & Great \\
\hline CFI & 0.934 & Acceptable \\
\hline GFI & 0.874 & Great \\
\hline AGFI & 0.845 & Acceptable \\
\hline $\begin{array}{l}\text { RMSEA(root mean squared } \\
\text { Error of Approximation) }\end{array}$ & 0.051 & Great \\
\hline PCLOSE & 0.416 & Great \\
\hline TLI & 0.925 & \\
\hline
\end{tabular}

From the result of model fit, all the indices is rather good. However, with the purpose achieving the best value of model fitness, the modification indices need to be considered to examine new whether covariance should be draw between two observed variables. The new covariance will be drawn when the modification indices are highest.

\begin{tabular}{|rrr|rr|}
\hline & & & M.I. & Par Change \\
\hline e20 & $<->$ & e21 & 73.363 & .429 \\
e18 & $<->$ & e19 & 50.109 & .297 \\
\hline
\end{tabular}

As we can see in the Modification indices above, there is a very high modification index between e20 and e21 as well as e8 and e9. Therefore, the new covariance should be drawn between these errors.

After drawing the new covariance, the model fit results is improved significantly. The GFI value increases to 0.894 , the RMSEA decrease to $0.037(<0.05)$ and the Chi-square also decreases to 1.345. These indices are sufficient to satisfy with the conditions in the table above. In conclusion, the model fit of CFA is highly adaptable the data 


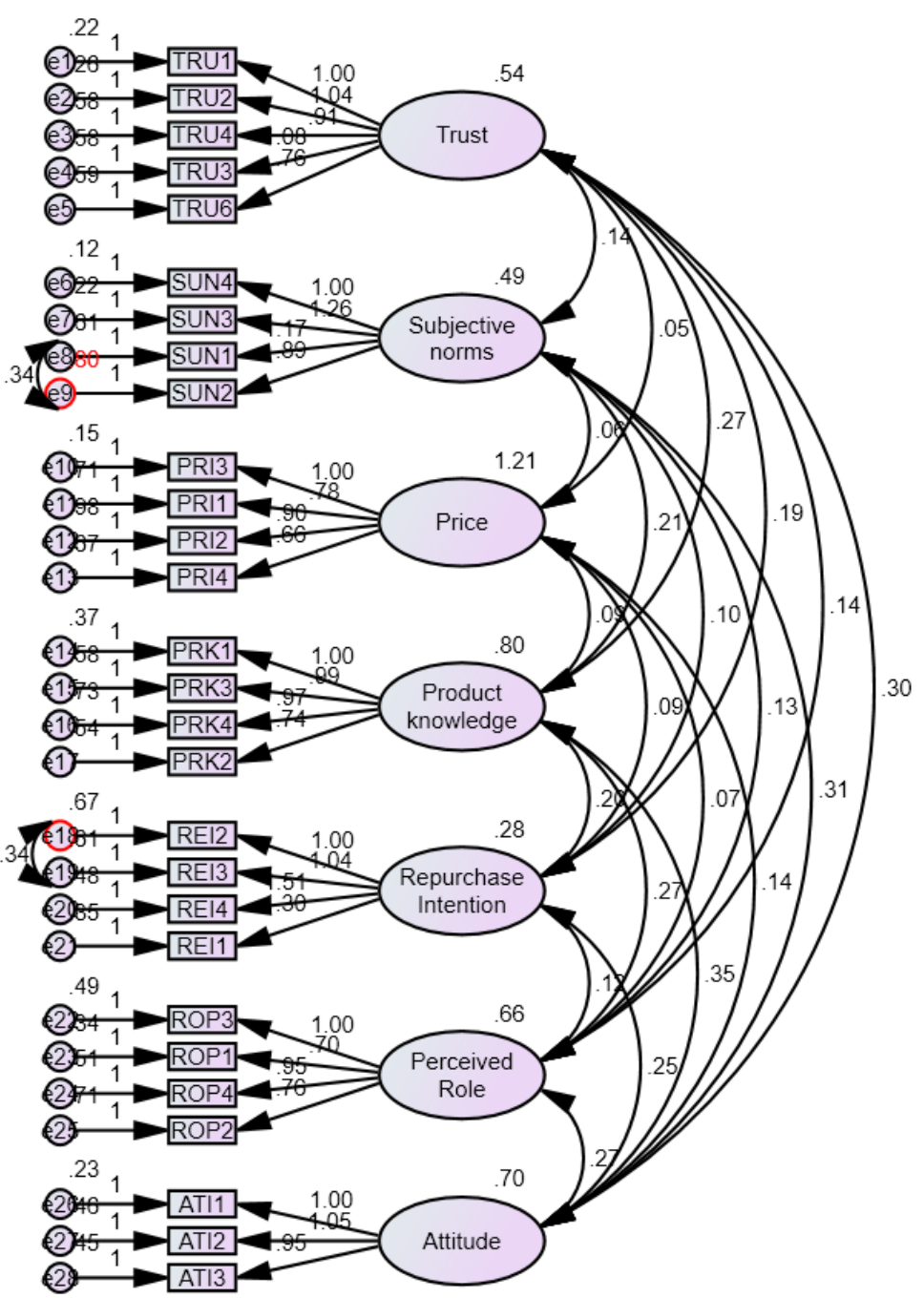

Chi-square $=439.858 ; d f=327 ; P=.000 ;$

Chi-square/df=1.345;

$\mathrm{GFI}=.894 ; \mathrm{TLI}=.960 ; \mathrm{CFI}=.966$;

RMSEA $=.037$ 


\section{Structural Equation Modeling (SEM)}

SEM is conducted with the purpose of testing the hypothesis relationships in the research model

Regression Weights: (Group number 1 - Default model)

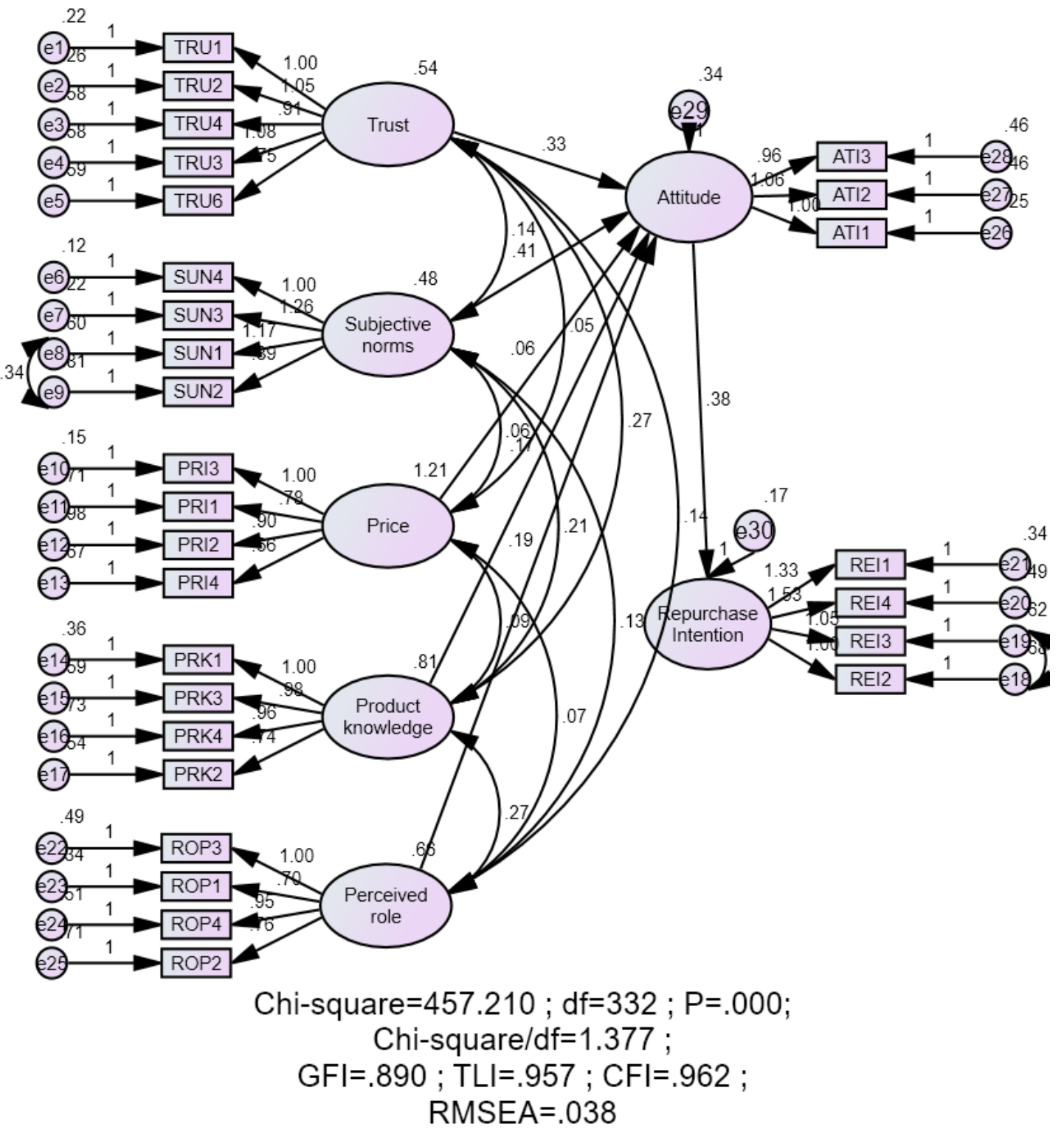




\begin{tabular}{|c|c|c|c|c|c|c|}
\hline & & & Estimate & S.E. & C.R. & $\mathrm{P}$ \\
\hline Attitude & $<<---$ & Trust & .330 & .073 & 4.512 & $* * *$ \\
\hline Attitude & $<---$ & Subjective_norms & .449 & .077 & 5.860 & $* * *$ \\
\hline Attitude & $<---$ & Price & .063 & .041 & 1.533 & .125 \\
\hline Attitude & $<---$ & Product_knowledge & .158 & .064 & 2.447 & .014 \\
\hline Attitude & $<---$ & Perceived_role & .181 & .067 & 2.718 & .007 \\
\hline $\begin{array}{l}\text { RepurchaseI } \\
\text { ntention }\end{array}$ & $<---$ & Attitude & .376 & .060 & 6.231 & $* * *$ \\
\hline
\end{tabular}

From the table, the p-value of Price and Attitude is 0.131 , which is greater than 0.05 , so the relationship between Price and Attitude is insignificant. The rest factors which are Subjective norms, Trust, Product knowledge and Perceived role are significantly related to Consumers' attitude with the $\mathrm{p}$ - value of less than 0.05 . In addition, the relationship between consumer's attitude and consumers' repurchase intention is also significant with the p-value of *** (less than 0.05). Therefore, there only has the hypothesis $\mathrm{H} 2$ will be rejected from the model 


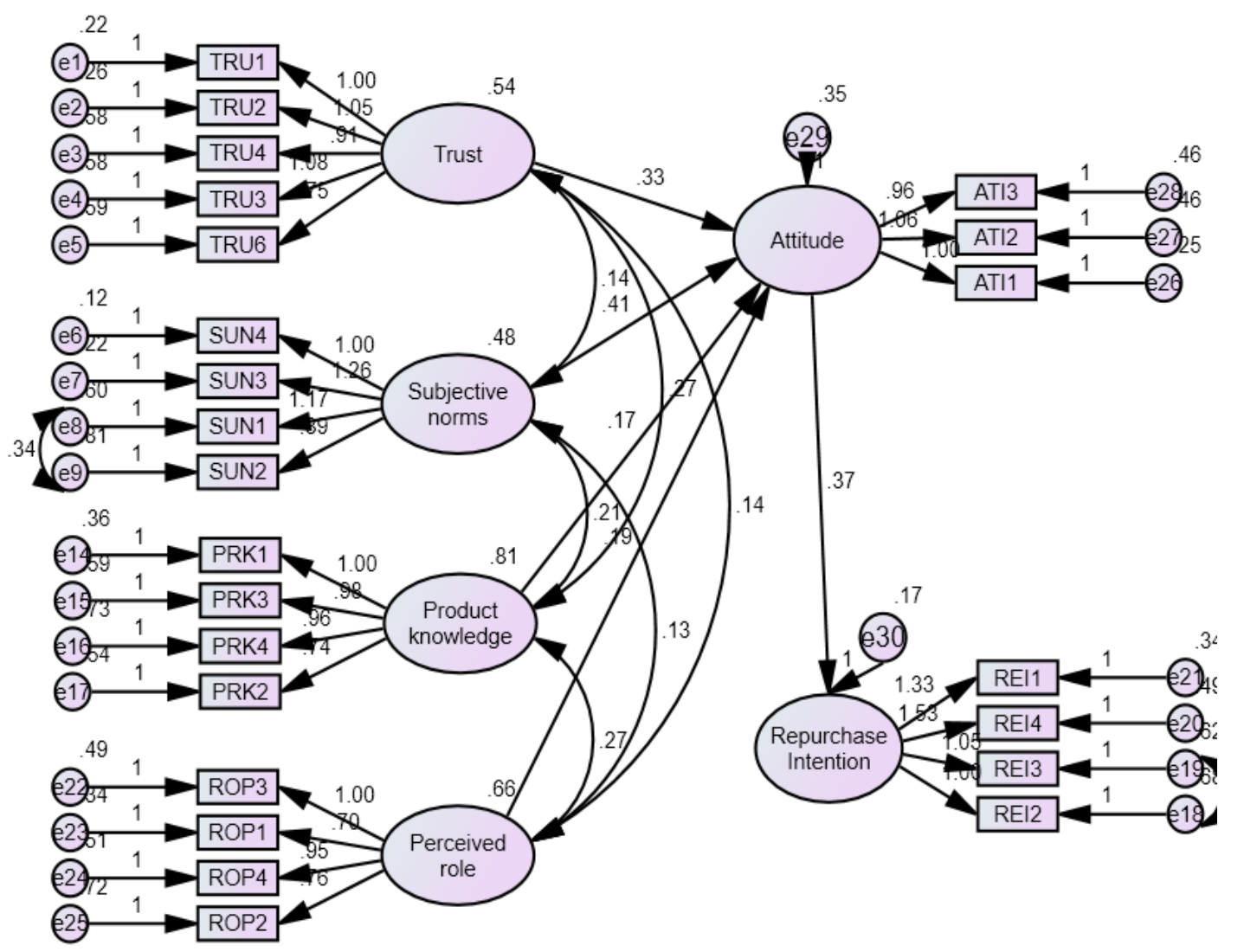

Chi-square=350.516; df=239; P=.000;

Chi-square/df=1.467;

GFI=.901; TLI=.954; CFI=.960 ;

RMSEA $=.042$

\begin{tabular}{|c|c|c|c|c|c|c|c|}
\hline & & & Estimate & S.E. & C.R. & $\mathrm{P}$ & Label \\
\hline Attitude & $<--$ & Trust & .330 & .074 & 4.450 & $* * *$ & \\
\hline Attitue & $<--$ & Subjective_norms & .414 & .075 & 5.556 & $* * *$ & \\
\hline Attitude & $<--$ & Product_knowledge & .170 & .065 & 2.612 & .009 & \\
\hline Attitude & $<--$ & Perceived_role & .189 & .068 & 2.798 & .005 & \\
\hline Repurchase_Intention & $<--$ & Attitude & .374 & .060 & 6.215 & $* * *$ & \\
\hline
\end{tabular}


Standardized Regression Weights: (Group number 1 - Default model)

\begin{tabular}{|lll|r|}
\hline & & & Estimate \\
\hline Attitude & $<---$ & Trust & .292 \\
Attitude & $<--$ & Subjective_norms & .347 \\
Attitude & $<---$ & Product_knowledge & .185 \\
Attitude & $<---$ & Perceived_role & .186 \\
Repurchase_Intention & $<---$ & Attitude & .597 \\
\hline
\end{tabular}

As the figure above, it can be seen that all indices are satisfied with the SEM criteria such as Chisquare $/ \mathrm{df}=1.467(<2), \mathrm{GFI}=0.901(>0.9), \mathrm{TLI}=0.954(>0.9), \mathrm{CFI}=0.960(>0.9)$ and $\mathrm{RMSEA}=$ $0.042(<0.08)$. The measurement model is totally fit the data.

\section{Bootstrap testing}

\begin{tabular}{|c|c|c|c|c|c|c|}
\hline Parameter & & SE & SE-SE & Mean & Bias & SE-Bias \\
\hline Attitude & $\begin{array}{ll}<--- & \text { Trust }\end{array}$ & .088 & .002 & .334 & .004 & .003 \\
\hline Attitude & <--- Subjective_norms & .084 & .002 & .417 & .003 & .003 \\
\hline Attitude & $<---\quad$ Product_knowledge & .075 & .002 & .168 & -.002 & .002 \\
\hline Attitude & <--- Perceived_role & .076 & .002 & .189 & .000 & .002 \\
\hline Repurchase_Intention & $<---\quad$ Attitude & .083 & .002 & .369 & -.005 & .003 \\
\hline
\end{tabular}

\begin{tabular}{|ll|r|}
\hline Parameter & & CR \\
\hline Attitude & $<--$ Trust & 1.333333 \\
Attitude & $<--$ Subjective_norms & 1 \\
Attitude & $<--$ Product_knowledge & -1 \\
Attitude & $<---$ Perceived_role & 0 \\
Repurchase_Intention $<---$ Attitude & -1.66667 \\
\hline
\end{tabular}


The CR value is less than 1.96, the research model is trustworthy

\section{Hypothesis checking}

\begin{tabular}{|c|c|c|}
\hline & Statements & Results \\
\hline H1 & $\begin{array}{l}\text { There is a positive relationship between consumer } \\
\text { knowledge and consumers' attitude }\end{array}$ & Accept \\
\hline $\mathrm{H} 2$ & $\begin{array}{l}\text { There is a positive relationship between Price and } \\
\text { consumers' attitude }\end{array}$ & Reject \\
\hline H3 & $\begin{array}{l}\text { There is a positive relationship between Subjective norms } \\
\text { and Consumers' attitude }\end{array}$ & Accept \\
\hline H4 & $\begin{array}{l}\text { There is a positive relationship between Trust and } \\
\text { Consumers' attitude }\end{array}$ & Accept \\
\hline H5 & $\begin{array}{l}\text { There is a positive relationship between Perceived role and } \\
\text { Consumers' attitude }\end{array}$ & Accept \\
\hline H6 & $\begin{array}{l}\text { Consumers' attitude has positive relationship to } \\
\text { consumers' repurchase intention }\end{array}$ & Accept \\
\hline
\end{tabular}

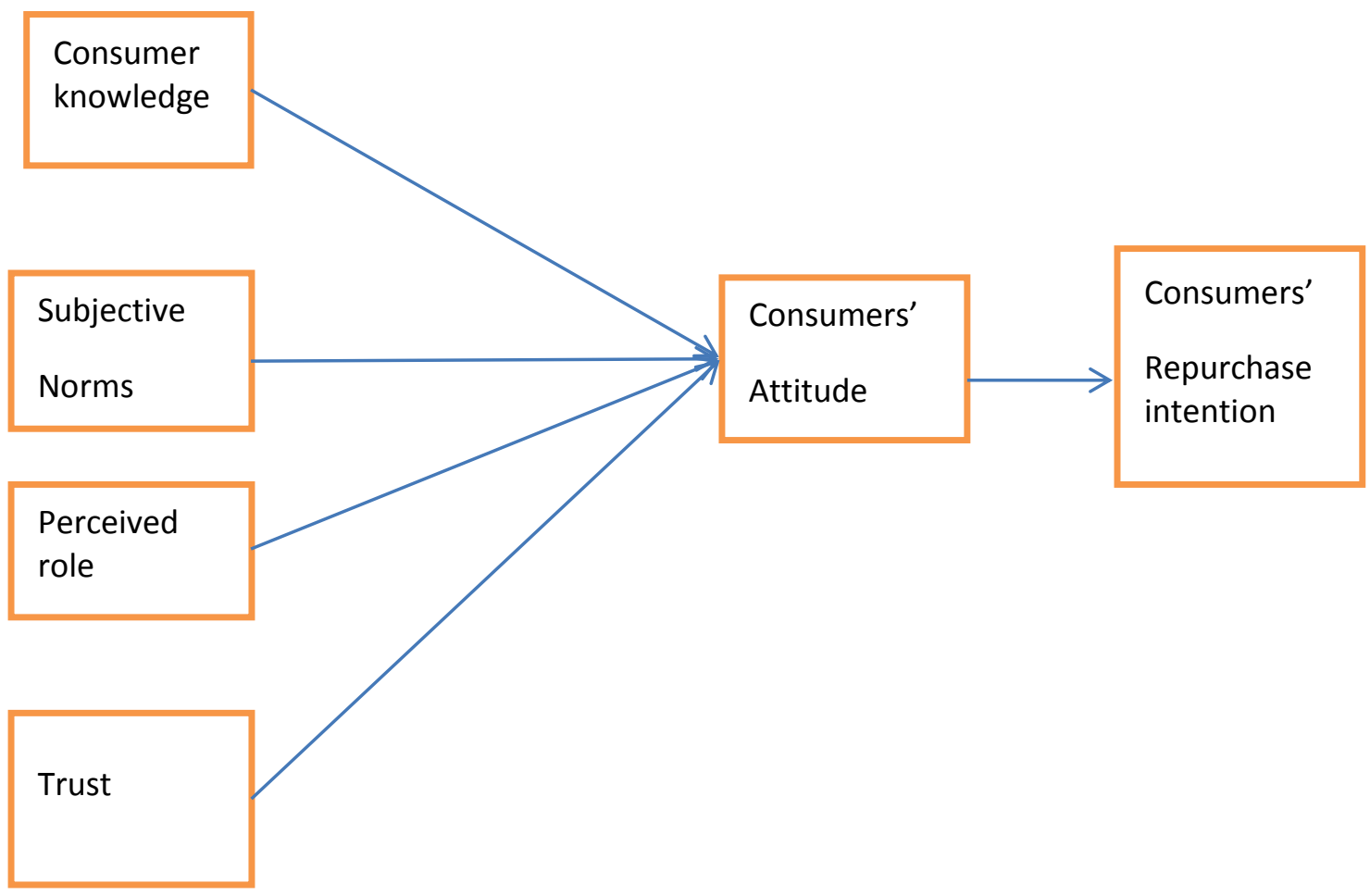




\section{CONCLUSIONS AND RECOMMENDATIONS}

\section{Discussion of the findings}

The results of this research aimed to respond to research's question put in the first chapter. The findings will be discussed and compared with the previous studies which are stated in the literature review part as following

\section{What kind of factors influence consumers' attitude toward functional foods?}

In the research, there are five factors are proposed for the impacts on consumer's attitude. However, after the analysis process, the results are shown as follow:

(1) Subjective norms: in this research, subjective norms positively influence to consumers' attitude towards functional foods and it matches with the Theory of Reason Action ([38]). This theory claims that purchase intention is the outcomes of consumers' attitude towards a product or service and there is a close link between consumer's attitude and subjective norms. It is easy to understand in Asia culture, especially Vietnamese culture because Asian consumers often make decisions based on the opinion of other people and response to what society expected to them more than choosing products based on their individual preferences. Therefore, people will have positive attitude towards functional foods when people around them such as relatives and friends highly appreciate the benefits of functional foods and recommends them use

(2) Trust: in this research, trust has profound influence on consumers' attitude and it is totally satisfied with the exploration of previous research such as the "Conceptual model of consumers' willingness to eat functional food" ([39]). This paper states that trust relates to benefit perceived from using functional foods, and it is the strongest factors affecting to consumers' willingness to buy these foods.

However, it is inconsistent with the study "Functional Food Choices: Impacts of Trust and Health Beliefs ([31]) about the level of influence on consumers' attitude. In this study, authors emphasize that perceived role is carried heavier weight than trust. However, in this research trust are weighted more heavily than perceived role among the factors affecting to consumers' attitude. The reason is that there are many functional foods are produced in Vietnam have ingredients from natural ingredients, so the effects of these functional foods may need more time to exert effects on consumers' health. Although these natural products need longer time to exert effects, they are totally safe for people. Therefore, with people who prefer 
natural -origin ingredients will have positive attitude based on their trust towards these products.

(3) Consumer knowledge: this factor is proposed based on the study "Consumer acceptance of functional foods: Socio - demographic, cognitive and attitudinal determinants. ([20]). In this study, the authors conclude that there is a difference in knowledge about functional foods across gender and education, and knowledge positively impacts on consumers' acceptance of functional foods. The results of this research are also in line with the investigation of Verbeke about the influence level of knowledge on consumers' acceptance. The more knowledge about functional foods people have, the more positive attitude they are.

(4) Perceived role: from the analysis process, this study examines that role perceived significantly impacts on consumers' attitude, which is similar to the results of the research "Functional Food Choices: Impacts of Trust and Health Beliefs ([31]). The author states that both trust and health perceived are the key factors affecting to consumer' attitude. The paper Consumers' acceptance of functional foods in Ho Chi Minh city ([37]) also complete agree with the important role of functional foods on consumers' acceptance in Ho Chi Minh city

(5) Price: price is not perceived as the influential factors towards functional foods in this research. It appears to contradict the study "Consumer acceptance of functional foods: socio - demographic, cognitive and attitudinal determinants" of Verbeke (2005) [20]. This study indicates that one of the main barriers for consumers' attitude and intention relates to very high price. The reason is that there have large number of variety functional foods in the market, and functional foods' prices are much competitive with each other and affordable for all segmentations. Another reason is that thanks to the development of technology, functional foods producers can produce high quality products with low cost, so it is not difficult to find a kind of quality functional foods without charging a high price. Moreover, other factors such as subjective norms, trust, consumer knowledge and perceived role have a great impact on consumers' attitude and dominate the factor of price. When people think about a kind of functional foods, they will consider about these factors and make decision rather than its price. Therefore,price of functional foods doesn't play an important role in consumers' attitude.

How does consumers' attitude impact on consumers' repurchase intention toward functional foods product? 
Consumers' attitude greatly impact on consumers' behavior based on the Theory of Planned behavior ([9]). From the research process, the author states that the consumers' behaviors towards a product are the consequence of consumers' attitude to this product. Therefore, this research based on this theory andinvestigate the relationship between consumers' attitude and repurchase intention. There are many previous research examine the relationship between consumers' attitude and purchase intention. For instance, the research "Consumer attitude and purchase intention towards organic food - A case study in China" conducted by Mingyan Yang, Sarah Al-Shaaban and Tram B. Nguyen (2014) [8]" examined that attitude have positive influence on consumer's purchase intention towards functional foods. The results of this study are in line with the previous research; however, this research explores the impacts of attitude on repurchase intention. Moreover,with the purpose of making it appropriate with Vietnamese market and functional foods market, some factors that affecting to consumers' attitude are changed.

\section{Recommendations}

Build consumers' trust by completing the legal framework for manufacturing and trading functional foods. Nowadays, one of the biggest challenges of the functional food industry is the lack of a clearly legal framework for production and trading, quality standards as well as how to manage and punish illegal activities. More and more negative phenomena with increasing levels are happening in the functional food market such as inaccurate or exaggerated information in the packaging, products that have not been examined and recognized by authorities, over advertising, counterfeit goods. This leads to lose consumers' trust towards functional foods. Consequently, this situation has seriously affected to the development of potential functional foods market in Vietnam. Therefore, businesses operating in this area need to coordinate with the authorities to develop legal system, standards, regulations and management regulations to protect their rights and benefits of businesses, step by step creating a solid foundation to maintain and rebuild consumers' trust. This is not only a right but also an obligation of businesses to supply safe and beneficial products for consumers

Enhance consumer awareness by emphasizing the message "Functional food is a nutritious food ". Not only experts like doctors but also consumers are increasingly aware of the close relationship between nutrition and health status ([29]). In order to meet the necessary nutrient demand, as well as provide nutrients to enhance health and prevent disease, besides normal foods, 
functional foods can be a good choice for bringing convenience and efficiency to consumers, especially those who are busy and pressured. Therefore, businesses need to send a clear message in their communication plan that functional food is a kind of food with added, enhanced nutrients to provide essential nutrients, strengthen resistance, and reduce the risk of disease.

Developing long-term plans aimed at introducing functional food to improve consumer knowledge. Knowledge of functional foods also has a significant impact on consumer acceptance. The more consumers understand about functional components as well as the effects of those components on health, the more they are likely to use functional foods. Therefore, businesses need to develop specific plans to spread the knowledge of functional foods to consumers. The implementation of the plan needs to be flexible, diverse, regular, easy to understand, attractive, abundant and also need to coordinate with other ways to improve knowledge of consumers by organizing workshop, TV programs with the participants of doctors or nutritionist, contest about nutrition.

\subsection{Limitations}

The first limitation of the research is the research sample. The questionnaires mainly are spread in district 1 and district 3 and there are only 260 valid responses. Therefore, the research's results can't reflect the entire population in Ho Chi Minh city

The second is about the factors including in the research. Besides factors from the studying, there may have many other factors that can impact on consumers' attitude and repurchase intention. Because of the limitation about finance and time period, the research can't examine all factors.

\section{Acknowledgements}

The author would like to thank Ms. Nguyen Ngoc Tuong Vy from School of Business, International University - Vietnam National University, HCMC for her editorial assistance.

Conflicts of Interest: The author(s) declare that there are no conflicts of interest regarding the publication of this paper. 


\section{References}

[1] Nguyen, N. T. Optimizing Factors for Accuracy of Forecasting Models in Food Processing Industry: A Context of Cacao Manufacturers in Vietnam. Ind. Eng. Manage. Syst. 18(4)(2019), 808-824.

[2] Nguyen, N. T., \& Tran, T. T. Raising opportunities in strategic alliance by evaluating efficiency of logistics companies in Vietnam: a case of Cat Lai Port. Neural Comput. Appl. 31(11)(2019), 7963-7974.

[3] Nguyen, N. T., \& Nguyen, L. X. T. Applying DEA Model to Measure the Efficiency of Hospitality Sector: The Case of Vietnam. Int. J. Anal. Appl. 17(6) (2019), 994-1018.

[4] Nguyen, N. T., \& Tran, T. T. Mathematical development and evaluation of forecasting models for accuracy of inflation in developing countries: a case of Vietnam. Discrete Dyn. Nat. Soc. 2015 (2015), Art. ID 858157.

[5] Nguyen, N. T., \& Tran, T. T. Facilitating an advanced product layout to prioritize hot lots in $450 \mathrm{~mm}$ wafer foundry in the semiconductor industry. Int. J. Adv. Appl. Sci. 3(6)(2016), 14-23.

[6] Nguyen, N. T., \& Tran, T. T. A Study of the Strategic Alliance for Vietnam Domestic Pharmaceutical Industry: A Dynamic Integration of A Hybrid DEA and GM $(1,1)$ Approach. J.Grey Syst. 30 (4) (2018), 134-151.

[7] Nguyen, N. T., \& Tran, T. T. A two-stage study of grey system theory and DEA in strategic alliance: An application in Vietnamese fertilizing industry. Int. J. Adv. Appl. Sci. 5(9)(2018), 73-81.

[8] Yang, M., Al-Shaaban, S., \& Nguyen, T. B. Consumer Attitude and Purchase Intention towards Organic Food: A quantitative study of China (Dissertation) (2014). Retrieved from http:/ / urn.kb.se/resolve?urn=urn:nbn:se:lnu:diva-34944

[9] Ajzen I., The Theory of Planned Behavior, Org. Behavior Human Decision Proc. 50 (1991), 179-211.

[10] Nguyen, N. T., Tran, T. T., Wang, C. N., \& Nguyen, N. T. Optimization of strategic alliances by integrating DEA and grey model. J. Grey Syst. 27(1)(2015), 38-56.

[11] Tran, T. T. Evaluating and forecasting performance using past data of an industry: An analysis of electronic manufacturing services industry. Int. J. Adv. Appl. Sci. 3(12)(2016), 5-20.

[12] Tran, T. T. An empirical research on selecting the targeted suppliers and purchasing process of supermarket. Int. J. Adv. Appl. Sci. 4(4) (2017), 96-109.

[13] Tran, T. T. Forecasting strategies and analyzing the numbers of incoming students: Case in Taiwanese vocational schools. Int. J. Adv. Appl. Sci. 4(9)(2017), 86-95.

[14] Wang, C. N., Nguyen, N. T., \& Tran, T. T. Integrated DEA models and grey system theory to evaluate past-to-future performance: a case of Indian electricity industry.Sci. World J. 2015(2015).Art. ID 638710. 
[15] Fornell, C., A national customer satisfaction barometer: The Swedish experience. J. of Market., 56(1) (1992), 6-21.

[16] Jackson, S. E., \& Schuler, R. S., A meta-analysis and conceptual critique of research on role ambiguity and role conflict in work settings. Org. Behavior Human Decision Proc., 36(1) (1985), 16-78.

[17] Ferrell, O. C., \& Pride, W. M., Marketing: concepts and strategies. Houghton Mifflin (1991).

[18] Eagly, A. H., \& Chaiken, S., The advantages of an inclusive definition of attitude. Social cognition, 25(5) (2007), 582-602.

[19] Siegrist, M, Sampfli, N and Kastenholz, H. Consumers' willingness to buy functional foods.The influence of carrier, benefit and trust.Appetite,51(2008), 526-529.

[20] Verbeke, W. Consumer acceptance of functional foods: socio-demographic, cognitive and attitudinal determinants. Food Qual. Prefer.16 (1) (2005), 45-57.

[21] Aarts, $\mathrm{H}$ and Dijksterhuis, A., The silence of the library: environment, situational norm,and social behaviour. J. Person. Soc. Psychol.84 (1) (2003), 18-28.

[22] Fogliano, V and Vitaglione, P. Functional Foods: Planning and Development. Mol.NutritionFood Res.49 (3) (2005), 256-262.

[23] Siró, I, Kapolna, E, Kapolna, B and Lugasi, A.Functional food.Product development,marketing and consumer acceptance - A review. Appetite, 51 (3) (2008), 456-467.

[24] Ares, G., Besio, M., Giménez, A., \& Deliza, R., Relationship between involvement and functional milk desserts intention to purchase. Influence on attitude towards packaging characteristics. Appetite, 55(2) (2010), 298-304.

[25] Annunziata, A., \& Vecchio, R., Consumer perception of functional foods: A conjoint analysis with probiotics. Food Quality and Preference, 28(1) (2013), 348-355.

[26] Childs, N. M., Foods that help prevent disease: consumer attitudes and public policy implications. J. of Cons. Marketing, 14(6) (1997), pp. 433-447. https:/ /doi.org/10.1108/07363769710186015

[27] Perkins, N. D., Post-translational modifications regulating the activity and function of the nuclear factor kappa B pathway. Oncogene, 25(51) (2006), 6717-6730. 
[28] Promotosh, B., \& Sajedul, I., Young consumers' purchase intentions of buying green products. A study based on the theory of planned behavior. Umea School of Business, Spring semester (2011).

[29] Menrad, K. Market and marketing of functional food in Europe.J. Food Eng.56 (2) (2003), 181-188.

[30] Shepherd, R.Social Determinants of Food Choice.Proceedings of the NutritionSociety, 58(04)(1999), 807-812.

[31] Ding, Y., Veeman, M. M., \& Adamowicz, W. L. Functional food choices: Impacts of trust and health control beliefs on Canadian consumers' choices of canola oil. Food Policy, 52(2015), 92-98.

[32] Moorman, C., Deshpande, R., \& Zaltman, G. (1993). Factors affecting trust in market research relationships. Journal of marketing, 57(1), 81-101.

[33] Urala, N and Lähteenmäki, L. Attitudes behind consumer's willingness to use functional foods.Food Qual. Prefer. 15(2004),793-803.

[34] Niva, M., 'All foods affect health': understandings of functional foods and healthy eating among health-oriented Finns. Appetite, 48(3) (2007), 384-393.

[35] Hilliam, M. Functional foods: the Western consumer view point. Nutrition Rev.54 (11) (1996), 189194.

[36] Bech-Larsen, T., \& Grunert, K. G., The perceived healthiness of functional foods: A conjoint study of Danish, Finnish and American consumers' perception of functional foods. Appetite, 40(1) (2003), 9-14.

[37] Nguyen, N.T. Performance Evaluation in Strategic Alliances: A Case of Vietnamese Construction Industry. Glob. J. Flex. Syst. Manage. 21(1) (2020), 85-99.

[38] Lähteenmäki, L. Consumers' changing attitudes towards functional foods. Food Qual. Prefer.18 (1) (2007), 1-12.

[39] Babicz-Zielinska, E., \& Jezewska-Zychowicz, M., Conceptual model of consumer's willingness to eat functional foods. Roczniki Państwowego Zakładu Higieny, 68(1) (2017). 